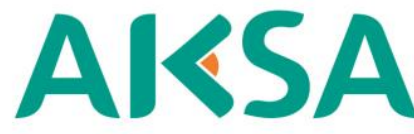

JURNAL DESAIN KOMUNIKASI VISUAL
AKSA: JURNAL DESAIN KOMUNIKASI VISUAL

ISSN: 2615-1111 (online)

Available online at:

http://aksa.stsrdvisi.ac.id

\title{
MITOS WANITA PADA DESAIN KEMASAN SABUN PEMBERSIH KEWANITAAN
}

\author{
Monica Revias Purwa Kusuma ${ }^{1}$, Aji Susanto Anom Purnomo ${ }^{2}$ \\ ${ }^{1}$ Institut Teknologi Telkom Purwokerto \\ ${ }^{2}$ Institut Seni Indonesia Yogyakarta \\ E-mail: revias@ittelkom-pwt.ac.id ${ }^{1}$, ajisusantoanom@isi.ac.id ${ }^{2}$
}

\begin{tabular}{|c|c|}
\hline ARTICLE INFO & ABSTRAK \\
\hline $\begin{array}{l}\text { Article history: } \\
\text { Received: 07 Oktober } 2020 \\
\text { Revised: } 23 \text { Oktober } 2020 \\
\text { Accepted: } 05 \text { November } 2020\end{array}$ & $\begin{array}{l}\text { A wider market in which there are various kinds of products makes } \\
\text { competition fierce for the attention of consumers. In plain view, } \\
\text { many similar items have almost similar visual elements, one of which } \\
\text { is feminine cleaning products. The feminine sanitizer packaging }\end{array}$ \\
\hline $\begin{array}{l}\text { Keywords: } \\
\text { Packaging design } \\
\text { Connotations meaning } \\
\text { Myths } \\
\text { Roland Barthes } \\
\text { Feminine cleansing }\end{array}$ & $\begin{array}{l}\text { bottle has a distinctive curve and is almost similar from one brand to } \\
\text { another. This study aims to examine a work of Visual } \\
\text { Communication Design in the form of packaging design of feminine } \\
\text { cleansing soap products. The feminine cleansing soap products } \\
\text { sampled were Herborist, Resik V, and Sumber Ayu, and all three } \\
\text { contain the same content, namely betel leaf extract. The research } \\
\text { method used in this research is descriptive qualitative with the theory } \\
\text { of the meaning of connotations and myths of Roland Barthes. The } \\
\text { results of the analysis of connotative and mythological meanings of } \\
\text { the three samples of feminine cleansing soap show that there are } \\
\text { similarities in the meanings of verbal and visual signs. These } \\
\text { products carry the same image which is constructed through the } \\
\text { connotations and myths of the hope of every woman to have a } \\
\text { fragrant, clean, healthy, healthy area of womanhood and does not } \\
\text { interfere with daily activities. Meanwhile, the meaning of myth in the } \\
\text { packaging design of feminine cleansing soap reveals that the shape } \\
\text { of the packaging design bottle is an ideal image of a woman's body. }\end{array}$ \\
\hline
\end{tabular}

\section{PENDAHULUAN}

Pasar yang semakin luas yang di dalamnya terdapat bermacam-macam produk membuat persaingan ketat demi mendapat perhatian para konsumen. Beragam cara dilakukan produsen untuk membidik target market mereka secara tepat. Salah satu cara dalam membidik target market secara tepat adalah menentukan segmen pasar terlebih dahulu. Segmen pasar adalah pelanggan potensial yang memiliki karakteristik yang sama saat menanggapi rencana pemasaran (Susanto \& Wijanarko, 2004). Salah satu segmentasi pasar demografis yang biasanya ditentukan oleh produsen untuk sebuah produk atau jasa adalah gender atau jenis kelamin. Segmentasi 
gender biasanya terlihat melalui elemen-elemen yang ditampilkan secara visual, misalnya pada warna, tipografi, bentuk kemasan, ilustrasi, ataupun fotografi.

Banyaknya produk-produk yang beredar di pasar secara tidak langsung terkadang membentuk keseragaman yang sekilas terlihat pada bentuk kemasannya, maupun elemen visual yang membentuknya. Di supermarket biasanya barang sejenis disusun dalam rak yang sama untuk mempermudah konsumen dalam melakukan pemilihan kebutuhan. Secara kasat mata banyak barang yang sejenis memiliki unsur visual yang hampir mirip, salah satunya yaitu produk pembersih kewanitaan. Hal pertama yang terlihat secara visual mirip yaitu bentuk botol kemasannya. Botol kemasan pembersih kewanitaan memiliki lekukan yang khas dan hampir mirip antara merk satu dengan yang lain. Produk pembersih kewanitaan sendiri sesuai dengan namanya memiliki segmentasi gender yang jelas yaitu untuk para wanita.

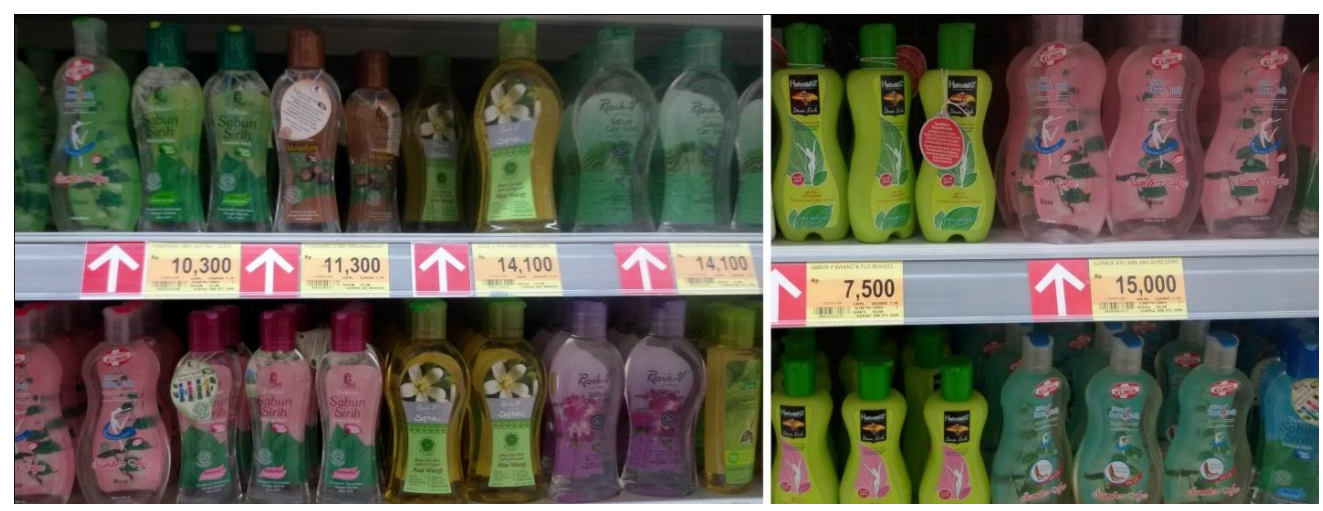

Gambar 1. Pembersih Kewanitaan dalam Sebuah Rak Supermarket

(Sumber: Dokumentasi Penulis)

Fungsi kemasan dahulu dan sekarang sudah mengalami pergeseran. Hal itu bisa dilihat dari fungsi kemasan yang tidak hanya melindungi suatu produk akan tetapi menjadi media untuk menyampaikan pesan suatu produk (Trisnanto, 2007). Seperti halnya pada kemasan pembersih kewanitaan yang pasti memiliki pesan yang ingin disampaikan melalui kemasannya. Teks yang dibalut oleh unsur visual dalam kemasan pembersih kewanitaan secara tidak langsung turut membentuk suatu identitas wanita di dalam masyarakat. Untuk mengetahui mitos wanita yang ingin dibangun dalam masyarakat melalui struktur/bentuk yang digunakan dalam produk pembersih kewanitaan, sebelumnya perlu diuraikan dahulu tanda visual dan tanda verbalnya. Kemudian, teori semiotika Roland Barthes nantinya digunakan untuk menganalisis latar belakang budaya melalui konotasi dan makna mitologis. Penandaan visual pada kemasan pembersih kewanitaan akan menghasilkan makna yang pada akhirnya mengacu pada hubungan 
antara nilai dan sikap. Di dalamnya termuat pesan-pesan yang sesuai dalam konteks kebudayaan masyarakat Indonesia yang menurut Barthes adalah sebuah mitos.

Pemaparan di atas mengantarkan pada rumusan masalah penelitian yaitu : Bagaimana mitos wanita yang dibentuk oleh kemasan pembersih kewanitaan?. Penelitian ini difokuskan pada beberapa produk-produk pembersih kewanitaan yang mempunyai kemiripan secara visual melalui struktur/bentuk botol kemasan dan elemen visual lain yang digunakan. Adapun merekmerek yang dijadikan sebagai obyek penelitian antara lain yaitu Herborist Daun Sirih, Resik V Sabun Cair Sirih, dan Sumber Ayu Sabun Daun Sirih.

Pentingnya penelitian ini diteliti karena merupakan fenomena unik dimana banyak produk pembersih kewanitaan memiliki kemasan yang mirip, serta bagaimana sebenarnya mitos wanita yang ingin dibangun dibaliknya. Hal-hal tersebut belum pernah diteliti sebelumnya dan mengugah peneliti untuk meneliti lebih lanjut. Diharapkan dengan adanya penelitian ini dapat menjadi literasi bagi pembaca yang ingin mengetahui mitos wanita dibalik kemasan suatu produk. Selain itu, dengan membaca penelitian ini diharapkan dapat menambah wawasan baru dalam memahami budaya visual di Indonesia khususnya pada desain kemasan.

\section{METODE PENELITIAN}

Metode yang digunakan pada penelitian ini adalah deskriptif kualitatif. Secara garis besar penelitian ini akan dilakukan dengan cara menganalisis obyek penelitian yaitu sabun pembersih kewanitaan. Sampel yang digunakan dalam penelitian ini yaitu kemasan Herborist Daun Sirih, Resik V Sabun Cair Sirih, dan Sumber Ayu Sabun Daun Sirih.

Penelitian ini dilakukan untuk mengetahui mitos wanita pada kemasan pembersih kewanitaan yang dijadikan obyek penelitian. Oleh karena itu, konten perlu dianalisis, yaitu melalui penggunaan teori utama dan penunjang. Teori utama untuk memaknai dan menganalisis secara interpretatif menggunakan teori semiotika, sedangkan teori penunjang akan menggunakan teori-teori Desain Komunikasi Visual yang termasuk di dalamnya mengenai desain kemasan.

Prosedur penelitian untuk mengetahui mitos wanita pada kemasan sabun pembersih kewanitaan dimulai dari studi pustaka, kemudian mencari teori yang relevan dengan penelitian tersebut. Ketika data penelitian sudah terkumpul, dapat dilanjutkan dengan analisis data yang hasilnya dapat memperkuat penelitian. Untuk teknik analisis datanya akan digambarkan pada alur berikut ini : 


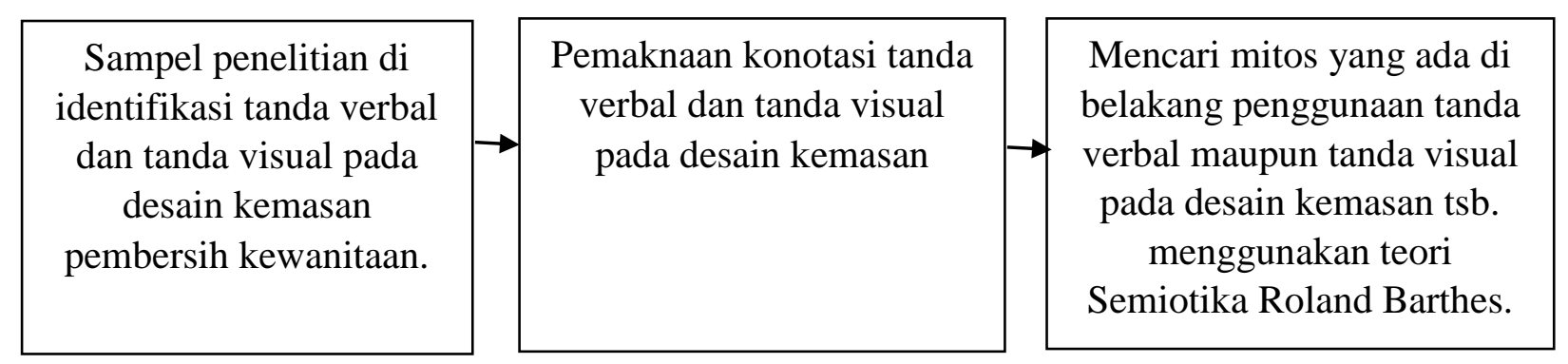

Metode analisis semiotika Roland Barthes diterapkan pada kemasan pembersih kewanitaan yang dipakai sebagai sampel pada penelitian ini. Teori inti Roland Barthes adalah gagasan mengenai sistem dua tatanan penandaan yaitu denotasi dan konotasi. Denotasi adalah sesuatu yang memiliki acuan anggapan umum atau bisa disebut sebagai makna yang terlihat pada suatu tanda. Sedangkan, makna konotasi adalah makna yang bisa menggambarkan interaksi yang muncul ketika tanda bertemu dengan emosi penggunanya serta nilai-nilai kultural dibelakangnya (Fiske, 2007). Sistem konotatif merupakan pendalaman dari sistem denotatif, dimana sistem konotatif yang mantap dapat berkembang menjadi mitos. Mitos seringkali tidak dibatasi dianggap sebagai makna tersembunyi yang secara sadar disepakati oleh masyarakat.

\section{PEMBAHASAN}

\subsection{Identifikasi Tanda Verbal dan Tanda Visual}
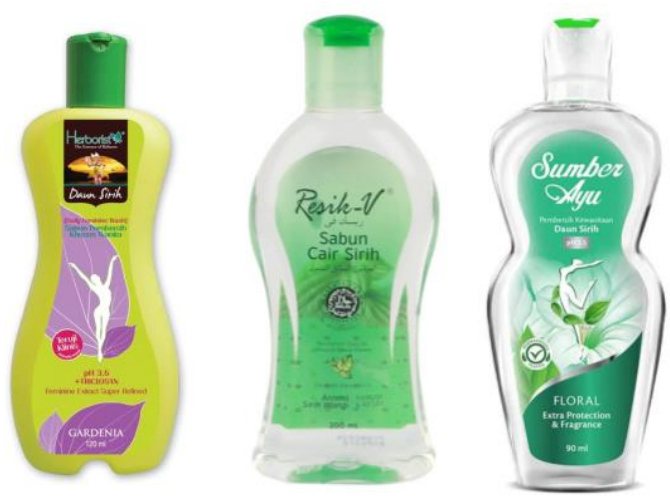

Gambar 2. Sampel Pembersih Kewanitaan yang Diteliti (Sumber: www.google.com)

Identifikasi tanda verbal dan tanda visual pada ketiga kemasan yang dijadikan sampel akan disajikan pada tabel di bawah ini :

\begin{tabular}{|c|l|l|}
\hline Merk & \multicolumn{1}{|c|}{ Tanda Verbal } & \multicolumn{1}{c|}{ Tanda Visual } \\
\hline Herborist & $\bullet \begin{array}{l}\text { Herborist The essence of } \\
\text { Baliness }\end{array}$ & $\bullet \begin{array}{l}\text { Bentuk botol melengkung yang menonjol di bagian atas } \\
\text { lalu meramping di bagian tengah dan kembali melengkung } \\
\text { di bagian bawah serta agak bolong di bagian tengah } \\
\text { bawah. }\end{array}$ \\
\hline
\end{tabular}




\begin{tabular}{|c|c|c|}
\hline Merk & Tanda Verbal & Tanda Visual \\
\hline & $\begin{array}{ll} & \text { (Sabun Pembersih } \\
& \text { kewanitaan) } \\
\text { - } & \text { Teruji Klinis } \\
\text { - } & \text { PH } 3,5+\text { triclosan } \\
\text { - } & \text { Feminine Extract Super } \\
& \text { Refined } \\
\text { - } & \text { Gardenia } \\
\text { - } & 120 \mathrm{ml}\end{array}$ & $\begin{array}{l}\text { - Warna botol hijau muda dan tutup hijau tua. } \\
\text { - Foto wanita Bali yang menari di bagian bawah teks } \\
\text { Herborist. } \\
\text { - Bulatan berwarna pink yang di dalamnya ada teks teruji } \\
\text { klinis } \\
\text { - Siluet seorang wanita dengan kedua tangan diangkat ke } \\
\text { atas. } \\
\text { - Ilustrasi daun berwarna ungu di belakang siluet wanita dan } \\
\text { bagian bawah di belakang teks Gardenia. }\end{array}$ \\
\hline Resik-V & $\begin{array}{l}\text { - Resik V } \\
\text { - Sabun Cair Sirih } \\
\text { - Majelis Ulama Indonesia } \\
\text { - Halal } \\
\text { - Pembersih Daerah Khusus } \\
\text { - Eewanitaan } \\
\text { - } \text { Arstrak Daun Sirih } \\
\text { - Harum dan Kesat } \\
\text { - } 200 \mathrm{ml}\end{array}$ & $\begin{array}{l}\text { - Bentuk botol melengkung dan menonjol di bagian atas } \\
\text { lalu meramping di bagian tengah dan membesar di bagian } \\
\text { bawah. } \\
\text { - Warna botol transparan, akan tetapi di bagian depan botol } \\
\text { berwarna hijau dan terdapat gambar daun. } \\
\text { - Ilustrasi daun yang ukuran kecil di atas tulisan ekstrak } \\
\text { daun sirih. } \\
\text { - Logo halal MUI. }\end{array}$ \\
\hline $\begin{array}{l}\text { Sumber } \\
\text { Ayu }\end{array}$ & $\begin{array}{l}\text { - } \text { Sumber Ayu } \\
\text { - Pembersih Kewanitaan } \\
\text { Daun Sirih } \\
\text { - } \text { PH } 3,5 \\
\text { - } \text { Dermatology Center } \\
\text { - } \text { Floral } \\
\text { - } \text { Extra Protection \& } \\
\text { - Fragrance } \\
\text { - } 60 \mathrm{ml}\end{array}$ & $\begin{array}{l}\text { - Bentuk botol melengkung yang menonjol di bagian atas } \\
\text { kemudian meramping di bagian tengah dan kembali } \\
\text { melengkung di bagian bawah. } \\
\text { - Warna botol transparan, akan tetapi di bagian depan } \\
\text { berwarna hijau. } \\
\text { - Siluet seorang wanita yang mengangkat tangan kesamping } \\
\text { dan satu kaki keatas. } \\
\text { - Ilustrasi daun di sekeliling siluet wanita } \\
\text { - Ilustrasi bunga sebagai background siluet wanita. }\end{array}$ \\
\hline
\end{tabular}

Tabel 1: Identifikasi Tanda Verbal dan Tanda Visual

(Sumber: Dokumentasi Penulis)

\subsection{Pembahasan}

Desain kemasan sebagai alat pemasaran suatu produk dapat mengkomunikasikan kepribadian atau fungsi produk konsumsi secara unik (Klimchuk, 2007). Begitu pula pada produk pembersih kewanitaan yang penulis kaji yaitu Herborist Daun Sirih, Resik V Sabun Cair Sirih, dan Sumber Ayu Sabun Daun Sirih. Keunikan desain kemasan produk tersebut terletak pada bentuk botol yang unik dan hampir mirip satu sama lainnya. Pada tabel 1 bisa dilihat bahwa ada beberapa poin pada identifikasi tanda visual yang memiliki kemiripan yang bisa dibaca melakui pemaknaan konotasi.

\subsubsection{Pemaknaan Tingkat Konotatif Pada Desain Kemasan Sabun Pembersih Kewanitaan}

Pada ketiga sampel sabun pembersih kewanitaan memiliki beberapa tanda yang memiliki kemiripan. Tanda pertama yang mirip dari ketiga sampel yang diteliti adalah bentuk botol yang tidak biasa. Botol tersebut memiliki lekukan yang menonjol di bagian atas dan meramping di bagian tengah, kemudian kembali menonjol di bagian bawah. Lekukan tersebut jika dilihat lebih dekat memiliki kemiripan dengan lekukan tubuh wanita. Pada bagian atas 
lekukan yang terlihat menonjol dapat dimaknai sebagai bagian dada seorang wanita. Pada bagian tengah yang meramping bisa dimaknai sebagai bagian perut seorang wanita. Sedangkan bagian bawah yang menonjol kembali bisa dimaknai sebagai pinggul bawah seorang wanita. Bentuk tersebut mengingatkan pula dengan gitar spanyol yang biasa dikatakan banyak orang seperti tubuh wanita yang ideal. Tanda-tanda tersebut bisa dimaknai lebih lanjut melalui pemaknaan konotatif yaitu gambaran tubuh wanita ideal menurut pandangan masyarakat.

Kemiripan tanda yang kedua adalah pada penggunaan warna hijau pada desain kemasan produk, walaupun jenis warnanya berbeda-beda. Warna hijau dapat dimaknai sesuatu yang berbau alam, natural, serta melambangkan kesejukan. Penggunaan warna hijau pada suatu produk biasanya bisa dimaknai bahwa produk sabun pembersih kewanitaan tersebut menggunakan bahan-bahan natural didalamnya.

Kemiripan tanda yang ketiga adalah pada ilustrasi daun yang ada pada ketiga desain kemasan sabun pembersih kewanitaan. Ilustrasi daun pada produk tersebut memiliki bentuk yang berbeda-beda. Ilustrasi daun pada ketiganya dibuat dengan teknik vector graphic, sedangkan pada gambar daun yang menjadi background di produk Resik-V menggunakan teknik fotografi. Melihat dari bentuk daun yang digambarkan pada setiap produk merujuk pada bentuk daun sirih. Hal ini juga diperkuat dengan adanya tanda verbal yang berupa teks 'daun sirih' pada ketiga kemasan tersebut. Penggunaan daun sirih sebagai ilustrasi yang ada pada ketiga produk tersebut bisa dimaknai sebagai bahan unggulan yang dipakai pada pembuatan sabun. Daun sirih merupakan suatu daun yang mengandung bahan antiseptik dan memiliki banyak khasiat serta sering dipakai pada pengobatan herbal. Hal ini dapat dimaknai sebagai kandungan daun sirih yang bersifat antiseptik menjadi bahan unggulan pada ketiga produk sabun tersebut. Daun sirih yang digunakan pada sebuah sabun pembersih kewanitaan dapat dimaknai bahwa kandungan tersebut dapat membantu daerah kewanitaan lebih bersih, menghilangkan gatal-gatal serta menghilangkan bau tak sedap.

Kemiripan keempat ada pada ilustrasi wanita yang digambarkan dengan siluet warna putih. Ilustrasi tersebut hanya terdapat pada produk Herborist dan produk Sumber Ayu. Ilustrasi siluet wanita di produk Herborist memiliki gestur tangan yang diangkat keatas dan kepala yang diangkat. Bagian kaki yang ada di siluet tersebut ada yang di depan dan satu di bagian belakang. Sedangkan pada produk Sumber Ayu, siluet wanita tersebut terlihat dari samping menaikkan kedua tangan dan dagu serta mengangkat satu kaki ke atas. Secara sekilas kedua tanda siluet wanita terlihat memiliki kemiripan secara visual. Tanda tersebut dapat dimaknai yaitu seorang wanita yang terlihat bebas dan bahagia dengan melihat gesture yang divisualisasikan oleh 
ilustrasi tersebut. Kebebasan dan kebahagiaan adalah dua hal yang diimpikan oleh setiap wanita ketika dihadapkan pada masalah-masalah kewanitaan. Masalah-masalah kewanitaan tersebut seringkali membuat sebuah situasi ketidaknyamanan yang sangat mengganggu aktivitas seharihari bagi seorang wanita. Ilustrasi ini dapat pula dimaknai sebagai sebuah citraan jawaban dari masalah-masalah tersebut dan harapan bagi wanita setelah menggunakan produk Herborist dan Sumber Ayu.

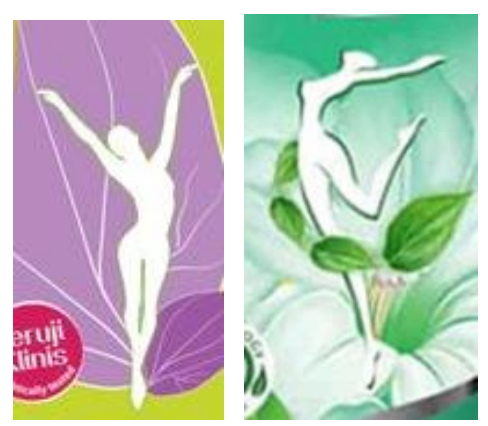

Gambar 3. Siluet wanita kiri Herborist dan bagian kanan Sumber Ayu (Sumber: www.google.com)

\subsubsection{Pemaknaan Mitos Pada Desain Kemasan Sabun Pembersih Kewanitaan}

Ketiga desain kemasan pembersih kewanitaan yang diteliti memiliki beberapa kemiripan tanda yang selanjutnya dapat dilihat dari segi mitos mengapa tanda tersebut muncul. Salah satu tanda yang terlihat mencolok adalah bentuk botol kemasan yang membentuk seperti lekukan tubuh seorang wanita. Tubuh seorang wanita yang dicitrakan melalui lekukan botol kemasan tersebut merupakan citraan mengenai mitos standar kecantikan dan keindahan yang ideal dan berlaku secara universal termasuk Indonesia. Pada kemasan tersebut pada bagian tengah botol terlihat ramping ke dalam. Hal tersebut serupa pada bagian perut wanita yang langsing. Seringkali mitos lekukan tubuh wanita tersebut dianalogikan dengan istilah "gitar spanyol", yang memiliki lekuk yang serupa dengan tubuh wanita di bagian dada dan pinggul bawah yang biasanya memiliki ukuran besar. Wanita yang memiliki badan yang besar di bagian dada dan pinggul bawah serta memiliki perut yang langsing lebih dinilai indah dan ideal. Hal tersebut oleh masyarakat juga biasanya disebut-sebut dengan tubuh wanita yang seksi. Wanita yang memiliki tubuh yang seksi juga dianggap lebih menarik oleh para pria, sehingga banyak wanita yang menjadikan hal tersebut menjadi tolak ukur. 


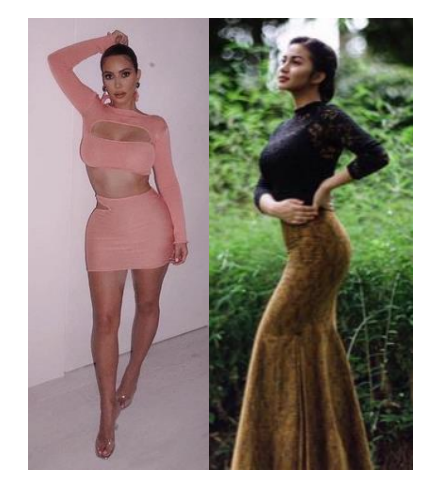

Gambar 4. Tubuh wanita Seksi (Sumber: www.google.com)

Ketiga kemasan sabun pembersih kewanitaan menggunakan bahan daun sirih sebagai ekstrak yang terkandung di dalamnya. Di desain kemasannya pun juga terdapat tanda visual daun yang jika dilihat dari struktur daunnya merupakan daun sirih. Daun Sirih dapat dimaknai secara mitos yaitu merupakan daun yang memiliki khasiat yang sangat banyak dan diyakini oleh masyarakat Indonesia salah satunya karena mengandung antiseptik. Daun sirih sendiri merupakan tumbuhan yang merambat dan biasa tumbuh di Indonesia. Beberapa kegunaan yang dimitoskan terdapat pada kegunaan daun sirih yaitu dapat menghilangkan gatal-gatal dan bau pada daerah kewanitaan serta dapat membuat bagian kewanitaan menjadi lebih kesat. Karena khasiat tersebut maka daun sirih sering digunakan sebagai ekstrak dalam pembuatan sabun pembersih kewanitaan yang dijual. Hal tersebut memunculkan mitos lain mengenai wanita yaitu sebagai wanita sudah seharusnya memiliki daerah kewanitaan yang wangi, bersih, kesat, dan terjaga kesehatannya. Akan tetapi, kontradiksi muncul karena dalam dunia kedokteran disebutkan bahwa membasuh daerah kewanitaan dengan sabun justru membuat bakteri baik mati dan mikro organismenya tidak terjaga lagi.

\section{KESIMPULAN}

Penelitian ini bertujuan untuk mengkaji suatu karya Desain Komunikasi Visual yang berbentuk desain kemasan dari produk sabun pembersih kewanitaan. Produk sabun pembersih kewanitaan yang dijadikan sampel adalah Herborist, Resik V, dan Sumber Ayu, dan ketiganya tersebut memiliki kandungan yang sama yaitu ekstrak daun sirih. Proses analisis diawali dengan identifikasi tanda verbal dan tanda visual pada desain kemasan pembersih kewanitaan. Lalu selanjutnya dilanjutkan dengan pemaknaan konotasi tanda verbal dan tanda visual yang ada pada desain kemasan tersebut. Pada tahap akhir analisis dilakukan pemaknaan mitos terhadap tanda-tanda verbal maupun visual yang mirip diantara ketiga kemasan tersebut. Pada 
pemaknaan konotasi dan mitos penulis menggunakan pendekatan teori Semiotika dari Roland Barthes.

Hasil analisis pada tahapan pemaknaan konotasi ketiga sampel sabun pembersih kewanitaan menunjukkan adanya kesamaan makna tanda verbal maupun tanda visual dari tiga produk tersebut. Kemiripan itu ditemukan pada bentuk botol kemasan, warna, ilustrasi/foto daun sirih, dan ilustrasi siluet wanita. Pemaknaan secara konotatif yang didapat oleh penulis dari beberapa kemiripan tersebut yaitu bentuk botol yang memiliki lekukan yang mirip dengan gambaran tubuh wanita ideal menurut pandangan masyarakat. Penggunaan warna hijau dalam desain kemasan suatu produk dapat dimaknai dengan penggunaan bahan alami organik pada produk tersebut. Ilustrasi atau foto daun sirih dan teks pendukung yang terdapat pada desain kemasan dapat dimaknai secara konotasi sebagai penggambaran dari sifat antiseptik yang dimiliki oleh daun sirih. Daun sirih tersebut merupakan bahan unggulan dari ketiga produk sabun tersebut. Siluet wanita yang terdapat dalam ilustrasi desain kemasan dapat dimaknai sebagai seorang wanita yang terlihat bebas dan bahagia tanpa khawatir akan kesehatan daerah kewanitaannya.

Pemaknaan mitos pada desain kemasan sabun pembersih kewanitaan mengungkapkan bahwa bentuk botol desain kemasan merupakan citraan tubuh wanita yang ideal yaitu tubuh yang berisi dan seksi. Mitos tubuh wanita yang ideal tersebut memiliki bagian dada dan pinggul bawah yang besar, namun memiliki perut yang langsing. Pada desain kemasan sabun pembersih kewanitaan juga ditemukan mitos lain yaitu penggunaan ekstrak daun sirih pada produk-produk tersebut. Daun sirih yang memiliki banyak khasiat sudah dipercaya secara turun temurun di Indonesia untuk menyembuhkan bermacam penyakit termasuk pada daerah kewanitaan. Produkproduk tersebut membawa kesamaan sebuah citra yang dikonstruksikan melalui makna konotatif dan mitos dari harapan setiap wanita untuk memiliki daerah kewanitaan yang wangi, bersih, kesat, sehat dan tidak mengganggu aktivitas sehari-hari.

\section{DAFTAR PUSTAKA}

Fiske, J. (2007). Cultural and Comunication Studies: Sebuah Pengantar Paling Komprehensif. Yogyakarta: Jalasutra.

Klimchuk, M. R. (2007). Desain Kemasan: Perencanaan merek produk yang berhasil mulai dari konsep sampai penjualan. Jakarta: Erlangga.

Susanto, A. ., \& Wijanarko, W. (2004). Power Branding: Membangun Merek Unggul dan

Organisasi Pendukungnya. Jakarta: Mizan Publika. 
Vol. 4, No. 1, November 2020, p. 578-587

Trisnanto, A. (2007). Cerdas Beriklan. Yogyakarta: Galang Press. 